\title{
Evaluation of Spatial land use/land cover changes due to Urbanization and Industrialization in Tirupur city using Remote Sensing
}

\author{
G. Krishnaraaju ${ }^{1 \#}$ and K. Elangovan ${ }^{2}$ \\ \{krishnaraaju@gmail.com, ela.civil@psgtech.ac.in²\} \\ Research Scholar, Department of Civil Engineering, PSG College of Technology, Coimbatore - \\ 641014, Tamil Nadu, India ${ }^{1}$. Professor, Department of Civil Engineering, PSG College of Technology, \\ Coimbatore -641014, Tamil Nadu, India ${ }^{2}$
}

\begin{abstract}
Rapid urbanization and expansion of cities due to population growth and industrialization have a significant effect on the environmental surroundings and land use/land cover. Remote sensing data obtained from Landsat satellite are used to study land use land cover changes (LULC) happening in Tirupur city and neighbourhood. In the present work,LULC maps were generated using Landsat data for the years 2001 and 2018 and the changes have been evaluated. The study reveals that there is maximum increase in built-up area and decrease in fallow lands between 2001 and 2018 with a slight change in crop land, waste land and scrub land. This change is attributed to the expansion of Tirupur city due to industrialization..
\end{abstract}

Keywords: Land use/landcover, Tirupur, Landsat, Change detection,Remote sensing, GIS, Supervised classification.

\section{Introduction}

Land use / land cover are interchangeable two separate terminologies: land cover implies the distribution of landscapes including water bodies, geo morphological features, forests and natural covers whereas land use refers to anthropogenic impact on land use build-up areas ${ }^{1}$. Land use/Land Cover (LULC) marks the environmental changes and land use plan in developing regions. There is a continuous change in the degradation process in the Earth due to exponential growth in population and urbanisation, subsequently there is a decrease in green cover and barren land ${ }^{2}$. Land use/land cover dataset is an important tool in assessing the change in land use pattern required for proper land management which plays a vital role for smart city development ${ }^{3,4}$.

Nowadays, satellite images of any area for any period of time is easily accessible from various sources all around the world which helps in creating LULC maps. This remote sensing technology has a wide multi-disciplinary application in urban planning, hydrology, water quality study, LULC, etc., at low cost with better accuracy ${ }^{5}$. High spatial resolution satellite imagery (up to30m) and advance open source image processing softwares with GIS technologies makes modelling and monitoring the LULC pattern often for any region ${ }^{6,7}$. Land area with faster development leads to urbanization process which has worsened the environmental scenario and therefore, it is required to determine the rate and trend of land cover/use conversion for devising a rational land use policy. Anthropogenic developments 
mainly due to the industrial growth, directly leads to the conversion of natural land cover to different land uses ${ }^{8}$. This present work focus on the combined use of remote sensing and GIS data to track the changes observed in the LULC study between the years $2001-2018$, for the semi-arid region of Tirupur corporation in the state of Tamilnadu, India.

\section{Study area}

Tirupur city is the fourth largest city in area in Tamilnadu, which extend between $77^{\circ} 11^{\prime}$ $43.74^{\prime \prime} \mathrm{E}$ to $77^{\circ} 23^{\prime} 18.14^{\prime \prime} \mathrm{E}$ longitude and $11^{\circ} 02^{\prime} 01.42^{\prime}$ ' $\mathrm{N}$ to $11^{\circ} 10^{\prime} 51.19^{\prime}$ ' $\mathrm{N}$ latitude and located at an average elevation of 295 metres from the mean sea level. Figure1 shows the geographical location of the study area. The total area of the Tirupur corporation is about 159.60 square kilometres which is divided into 60 wards and records a population of 4,44,352 as per the 2011 census. Tirupur has a tropical climate with a temperature ranging from $22^{\circ} \mathrm{C}$ to $37^{\circ} \mathrm{C}^{9,10}$. The city records rainfall during the south-west monsoon in the months from June to August and a considerable amount of rainfall from the north-east monsoons are also recorded from the month of October to November. The city records an average rainfall of around $700 \mathrm{~mm}$ with south-west and north-east contributing about $28 \%$ and $47 \%$ respectively to the total rainfall.

River Noyyal runs at the heart of the city and get often flooded during monsoon season. Tirupur is also known as the knitwear capital of India and prompted as the textile industry in India for the past three decades. The soil is black cotton soil which is suitable for cotton cultivation, red loamy soil is also found in some parts. In the late 1970s, agriculture was the main source of economy of the Tirupur ${ }^{11}$. Later the farmers become owners of small textile related units. The tremendous growth in the textile industries made Tirupur as the India's textile hub with more of investors. This industrial development made Tirupur as a corporation in the year 2008. But, the city also faces severe environmental problems, due to the untreated waste water from the dying and bleaching industries, discharges into the open streams and lakes $^{12}$.

\section{Methodology}

Data Acquisition

The present study investigates the land use / land cover change (LULCC) from 2001 to 2018 through Landsat 5 and Landsat 8 satellite images, whose data acquisition details are given in Table1.

Table1 Satellite data details

$\begin{array}{llllll}\text { Year } & \text { Data Used } & \text { Sensor } & \text { Resolution } & \text { Path/Row } & \begin{array}{l}\text { Date } \\ \text { Acquisition } \\ 23^{\text {rd }} \text { Feb 2001 }\end{array} \\ \mathbf{2 0 0 1} & \begin{array}{l}\text { Landsat 5 C1 Level- } \\ 1\end{array} & \text { TM } & 30 \mathrm{~m} & 144 / 052 & \text { of } \\ \mathbf{2 0 1 8} & \text { Landsat 8 Level 1 } & \text { OLI / TIRS } & 30 \mathrm{~m} & 144 / 052 & 06^{\text {th }} \text { Feb 2018 }\end{array}$

The Landsat satellite date was selected because of its free availability with high resolutions. The data set were obtained from the United State Geological Survey (USGS) earth explorer site (http://earthexplorer.usgs.gov/) ${ }^{13}$.These datasets were imported in ERDAS 
Imagine, satellite image processing software to create a false colour composite (FCC). To process and analysis the data, software QGIS 2.18 was used ${ }^{14,15}$. The supporting study area boundary was collected from the Tirupur Corporation and it is shown in Figure 1.

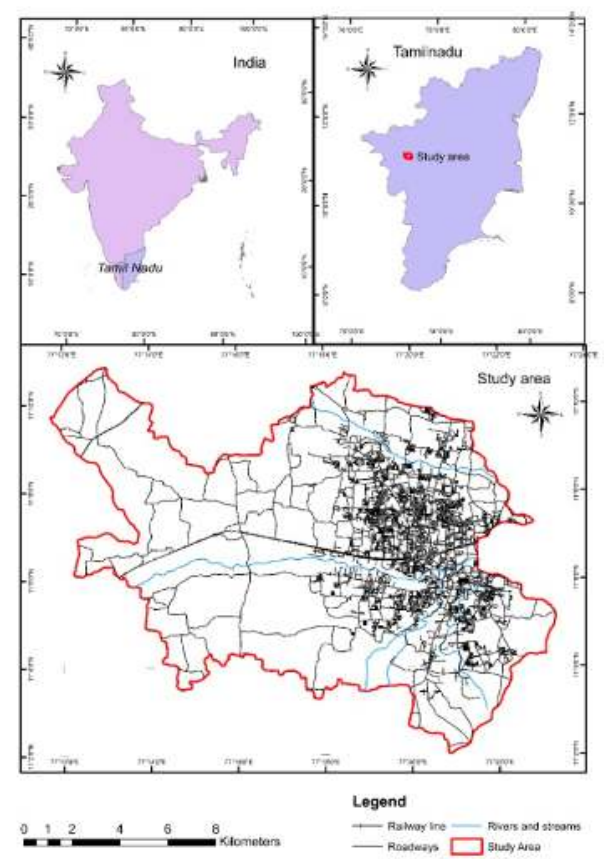

Figure 1. Map Showing the study area

Image Processing and Classification

Satellite images were layer stacked using image interpreter tool box in Erdas Imagine software and the study area is extracted using raster sub-set tool for the geo-referenced boundary of Tirupurcity as AOI (Area of Interest). Supervised classification has been carried out for the raster image where the pixel signatures for differentland cover types are captured by drawing delimiting polygons around the respective sites from the satellite imagery are stored as signature files and the raw digital numbers (DN) of each pixel was converted to radiance values, that belongs to a particular class of land use ${ }^{16}$. Maximum likelihood algorithm method was chosen for supervised classification where the accuracy assessment using kappa methods was done. However, to reduce the misclassifications due to heterogeneous mixture of features such as building, vegetation, bushes etc., visual interpretation is also made for enhancing the classification accuracy and to improve the quality of LULC map produced ${ }^{17,18}$.

Seven types of land use/cover are identified in the study region namely built-up land, agriculture - crop land, current fallow, plantation, wasteland, scrub forest and water bodies. The description of each class is given in the Table 2and each class was assigned with a particular colour ${ }^{19}$.

Table 2Land Use Classes defined on the basis of supervised classification.

SL

No
Class Name
Description
Colour Code Used (RGB) 
All man-made constructions including residential,

\begin{tabular}{|c|c|c|c|}
\hline 1 & Built - up & $\begin{array}{l}\text { commercial,industrial, transportation utilities } \\
\text { and services, etc., }\end{array}$ & $255,0,0$ \\
\hline & $\begin{array}{l}\text { Agriculture - } \\
\text { crop land }\end{array}$ & Agriculture land withcrop cultivation & $158,81,43$ \\
\hline & $\begin{array}{l}\text { Current } \\
\text { fallow }\end{array}$ & $\begin{array}{l}\text { Agriculture land kept ideal for one or two years } \\
\text { with cultivation }\end{array}$ & $245,245,219$ \\
\hline & Plantation & Mainly tree plantation like coconut & $0,204,0$ \\
\hline & Wasteland & $\begin{array}{l}\text { exposed soil and barren area } \\
\text { influenced by human influence }\end{array}$ & $209,181,133$ \\
\hline & Scrub forest & Includes bushes, plants which are not cultivated, & $115,184,43$ \\
\hline & Water bodies & $\begin{array}{l}\text { Includes river, open water, lakes, ponds, streams } \\
\text { andreservoirs }\end{array}$ & $0,158,222$ \\
\hline
\end{tabular}

The area coverswith seven land use classes in as depicted in Figure 2 (a) for the years 2001 and Figure 2 (b) for 2018 and the data given in Table 3 accounts for the area cover in hectare for each classes comprising the total area 18913.98 hectare of Tirupur city. Analysis of the data clearly proves that there is a change in the land use.

The main change in land use in largely noted to a depreciation of $17.52 \%$ in current fallow land and intensification growth in built-up land of about $12.76 \%$. Whereasa minimal increase in land use change is noted for agricultural - crop land \&plantation land, waste land, scrub forest to about $2.04 \%, 0.10 \%, 1.29 \%$ and $1.34 \%$ respectively.

The growth and decline in the land use classes for the study area of Tirupur city is clearly revealed from the data shown in Table 3 and Figure 2, 3\&4. For the period from 2001 to 2018 there is an increase in built-up area from 2454.60 hectare to 4868.04 hectare which accounts to about $12.76 \%$ in land use change. The agricultural - crop and plantation land has increased by about $2.14 \%$ from accounting a change from 1612.64 hectare to 2016.23 hectare. The waste land and scrub forest area have also increased from 23.72 to 268 hectare and 12.94 to 266.18 hectare respectively, where current fallow land contributes more for this conversion.

The current fallow land has been decreased from 14775.21 hectare to 11462.39 hectare. This accounts for highest depreciation in the LULC change for the last decade and records to $17.52 \%$ decrease. It is noted that, there is an appreciable change in the water body class, which is mainly focused in change in location than change is total area cover. The encroachment along the bundsof the water bodies was one of the reason for this change in location. 


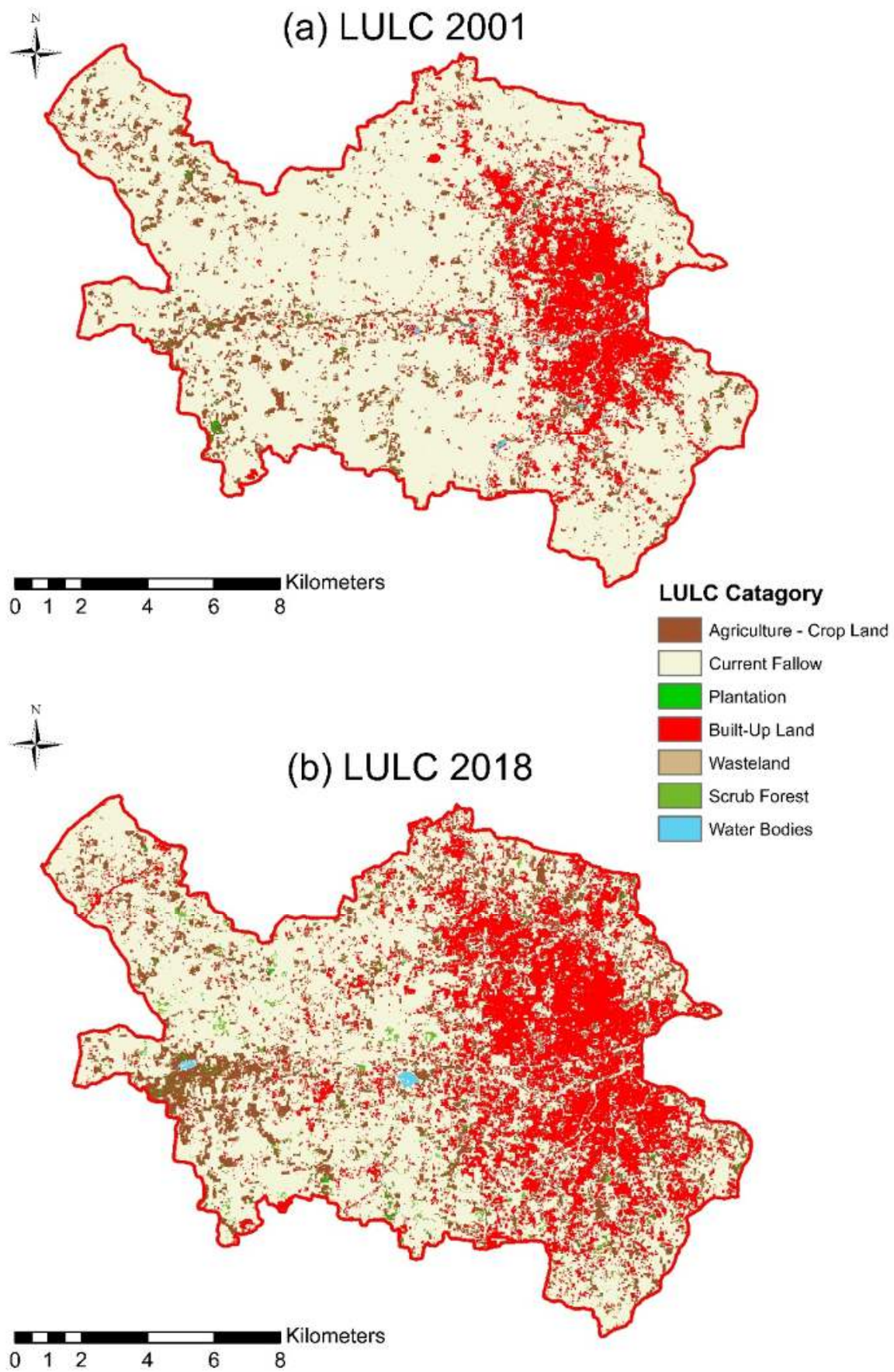


Figure 2 (a) Classified maps of Tirupur in 2001\&(b) Classified maps of Tirupur in 2018 Table 3 LULC change deduction from 2001 to 2018

\begin{tabular}{|c|c|c|c|c|c|c|}
\hline \multirow{2}{*}{ Land use Classes } & \multicolumn{2}{|l|}{ Year - 2001} & \multicolumn{2}{|l|}{ Year - 2018} & \multicolumn{2}{|c|}{$\begin{array}{l}\text { Difference between } \\
2001-2018\end{array}$} \\
\hline & Area in hect & Area in $\%$ & Area in hect & Area in $\%$ & Area in hect & Area in $\%$ \\
\hline Built-Up Land & 2454.60 & 12.98 & 4868.04 & 25.74 & 2413.44 & 12.76 \\
\hline Current Fallow Land & 14775.21 & 78.12 & 11462.39 & 60.60 & -3312.82 & -17.52 \\
\hline $\begin{array}{l}\text { Agriculture - Crop } \\
\text { Land }\end{array}$ & 1578.67 & 8.35 & 1964.11 & 10.38 & 385.44 & 2.04 \\
\hline Plantation & 33.97 & 0.18 & 52.12 & 0.28 & 18.15 & 0.10 \\
\hline Water Bodies & 34.87 & 0.18 & 33.07 & 0.17 & -1.80 & -0.01 \\
\hline Waste Land & 23.72 & 0.13 & 268.07 & 1.42 & 244.35 & 1.29 \\
\hline Scrub Forest & 12.94 & 0.07 & 266.18 & 1.41 & 253.24 & 1.34 \\
\hline Total & 18913.98 & 100 & 18913.98 & 100 & 0 & 0 \\
\hline
\end{tabular}

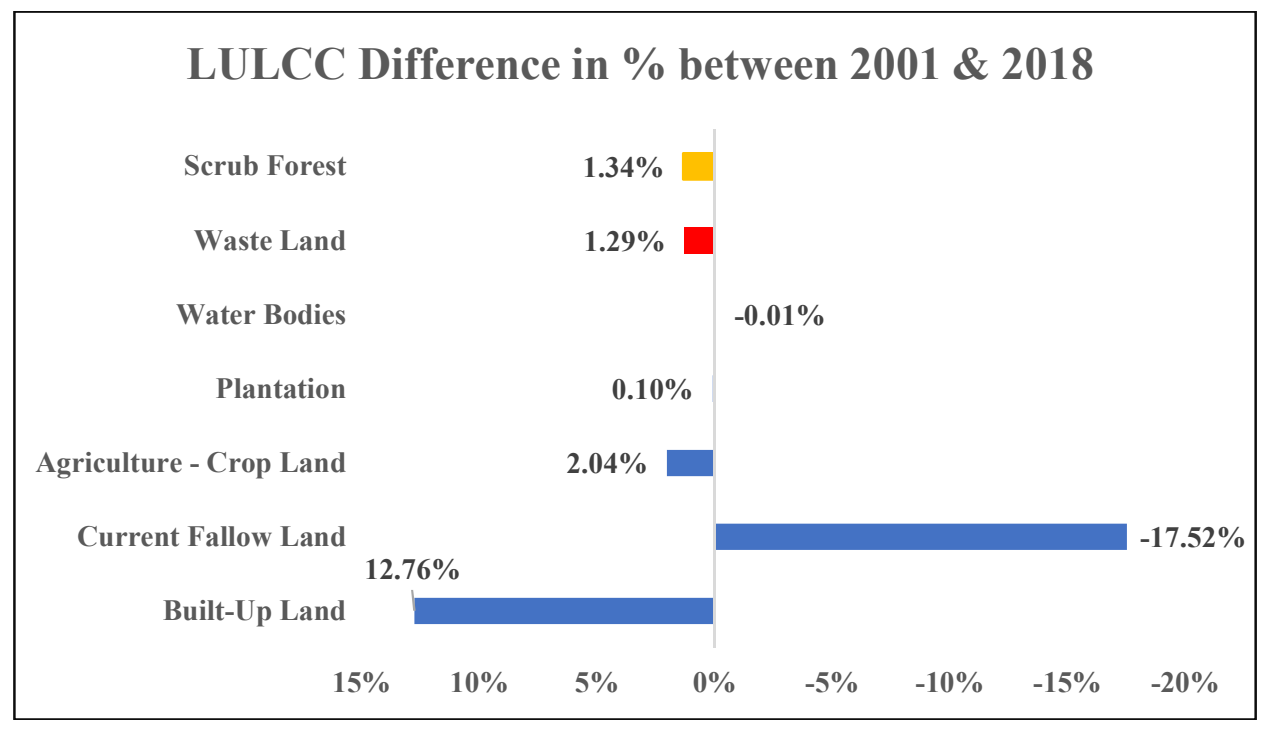

Figure 3 Graphical representation of LULCC \% for the last decade in the study area

Table 4 Matrix showing the LULCclass conversion from 2001 to 2018

To LULC class in year 2018 (area in hect)

\begin{tabular}{|c|c|c|c|c|c|c|}
\hline $\begin{array}{l}\text { Built-Up } \\
\text { Land }\end{array}$ & $\begin{array}{l}\text { Current } \\
\text { Fallow } \\
\text { Land }\end{array}$ & $\begin{array}{l}\text { Agricultur } \\
\text { e - Crop } \\
\text { Land }\end{array}$ & Plantation & $\begin{array}{l}\text { Water } \\
\text { Bodies }\end{array}$ & $\begin{array}{l}\text { Waste } \\
\text { Land }\end{array}$ & $\begin{array}{l}\text { Scrub } \\
\text { Forest }\end{array}$ \\
\hline - & 377.73 & 15.57 & 0 & 8.91 & 27.36 & 2.43 \\
\hline
\end{tabular}




\begin{tabular}{|c|c|c|c|c|c|c|c|}
\hline $\begin{array}{l}\text { Current } \\
\text { Fallow }\end{array}$ & 2704.95 & - & 1249.38 & 34.38 & 17.01 & 215.1 & 218.61 \\
\hline $\begin{array}{l}\text { Land } \\
\text { Agricultu }\end{array}$ & & & & & & & \\
\hline $\begin{array}{l}\text { re - Crop } \\
\text { Land }\end{array}$ & 80.91 & 742.59 & - & 15.57 & 1.17 & 21.15 & 42.48 \\
\hline Plantation & 1.17 & 6.57 & 14.58 & - & 0 & 1.8 & 0.99 \\
\hline $\begin{array}{l}\text { Water } \\
\text { Bodies }\end{array}$ & 4.23 & 18 & 7.29 & 0.36 & - & 0.27 & 0.18 \\
\hline $\begin{array}{l}\text { Waste } \\
\text { Land }\end{array}$ & 13.05 & 6.39 & 0.27 & 0.36 & 1.44 & - & 0.09 \\
\hline $\begin{array}{l}\text { Scrub } \\
\text { Forest }\end{array}$ & 2.16 & 0 & 2.52 & 0.27 & 0 & 0.18 & - \\
\hline
\end{tabular}

\section{LULC changes in land class from 2001 to 2018}

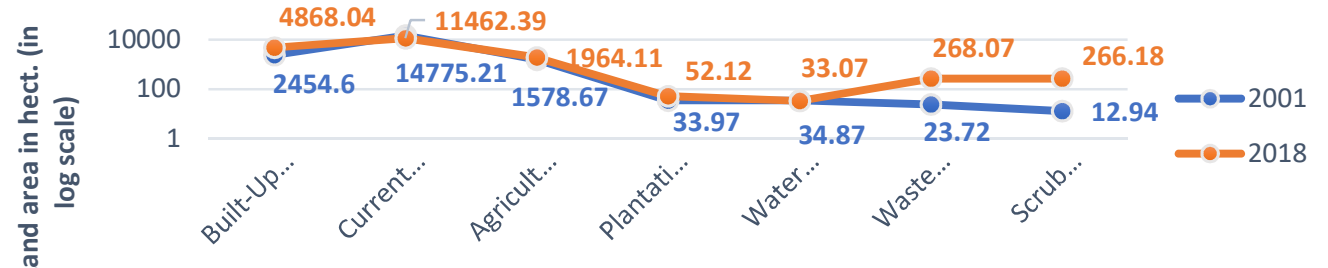

Figure 4 Graphical representation of LULC change area (in hect.) in log scale from 2001

to 2018
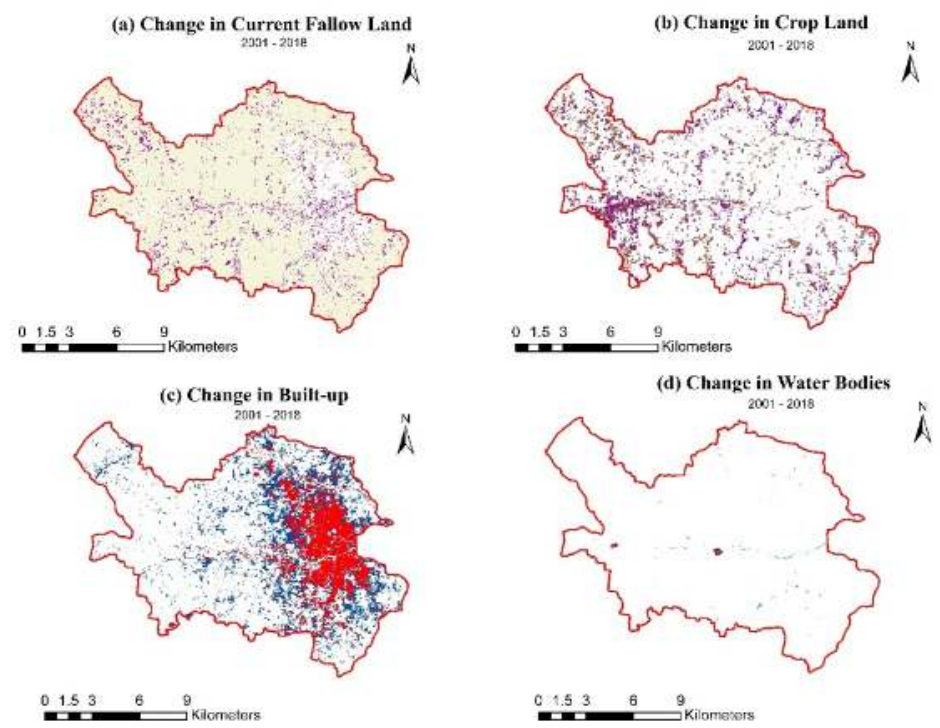

Figure 5 Land use/land cover change during 2001-2018 in Tiruppur Municipality(a) Fallow land (b) crop land (c) Built-up(d) water bodies (based on Landsat Satellite Image) 
Ground Truth Verification

Ground truth verification as shown in Table 5 was carried out at field with the help of hand held GPS for each land classes. Figure 2 (b) LULC classified map was used for verification along with the field data. Minimum of three points for each class was chosen randomly, then longitudinal and latitude of that points were collected in the field, later it was verified with the LULC generated map. It is found that all the land use classes are found correct and match with the real world.

Table 5 Ground truth verification

\begin{tabular}{|c|c|c|c|c|}
\hline $\begin{array}{l}\text { Sl } \\
\text { No }\end{array}$ & Latitude & Longitude & Land use class & $\begin{array}{l}\text { Ground truth } \\
\text { Confirmed }\end{array}$ \\
\hline 1 & $11^{\circ} 4^{\prime} 43.763^{\prime \prime} \mathrm{N}$ & $77^{\circ} 17^{\prime} 10.072^{\prime \prime} \mathrm{E}$ & Built up & Yes \\
\hline 2 & $11^{\circ} 9^{\prime} 56.424^{\prime \prime} \mathrm{N}$ & $77^{\circ} 18^{\prime} 29.737^{\prime \prime E}$ & Built up & Yes \\
\hline 3 & $11^{\circ} 7^{\prime} 35.513^{\prime \prime N}$ & $77^{\circ} 20^{\prime} 39.084^{\prime \prime E}$ & Built up & Yes \\
\hline 4 & $11^{\circ} 7^{\prime} 47.174^{\prime \prime N}$ & $77^{\circ} 21^{\prime} 54.3^{\prime \prime} \mathrm{E}$ & Current Fallow Land & Yes \\
\hline 5 & $11^{\circ} 4^{\prime} 36.562^{\prime \prime N}$ & $77^{\circ} 22^{\prime} 47.272^{\prime \prime} \mathrm{E}$ & Current Fallow Land & Yes \\
\hline 6 & $11^{\circ} 4^{\prime} 32.627^{\prime \prime} \mathrm{N}$ & $77^{\circ} 15^{\prime} 37.987^{\prime \prime E}$ & Current Fallow Land & Yes \\
\hline 7 & $11^{\circ} 5^{\prime} 19.741^{\prime \prime} \mathrm{N}$ & $77^{\circ} 16^{\prime} 37.95^{\prime \prime} \mathrm{E}$ & Current Fallow Land & Yes \\
\hline 8 & $11^{\circ} 5^{\prime} 10.863 " \mathrm{~N}$ & $77^{\circ} 23^{\prime} 8.113^{\prime \prime E}$ & $\begin{array}{l}\text { Agriculture - Crop } \\
\text { Land }\end{array}$ & Yes \\
\hline 9 & $11^{\circ} 4^{\prime} 46.114^{\prime \prime} \mathrm{N}$ & $77^{\circ} 16^{\prime} 22.14^{\prime \prime} \mathrm{E}$ & $\begin{array}{l}\text { Agriculture - Crop } \\
\text { Land }\end{array}$ & Yes \\
\hline 10 & $11^{\circ} 7^{\prime} 58.463^{\prime \prime} \mathrm{N}$ & 77¹9'2.792"E & $\begin{array}{l}\text { Agriculture - Crop } \\
\text { Land }\end{array}$ & Yes \\
\hline 11 & $11^{\circ} 3 ' 35.618^{\prime \prime} \mathrm{N}$ & $77^{\circ} 17^{\prime} 36.449^{\prime \prime E}$ & Plantation & Yes \\
\hline 12 & $11^{\circ} 6^{\prime} 33.142^{\prime \prime} \mathrm{N}$ & $77^{\circ} 14^{\prime} 3.698^{\prime \prime} \mathrm{E}$ & Plantation & Yes \\
\hline 13 & $11^{\circ} 7^{\prime} 36.627^{\prime \prime N}$ & $77^{\circ} 21^{\prime} 36.496 " \mathrm{E}$ & Plantation & Yes \\
\hline 14 & $11^{\circ} 6^{\prime} 4.874^{\prime \prime} \mathrm{N}$ & $77^{\circ} 17^{\prime} 37.847 " \mathrm{E}$ & Water Bodies & Yes \\
\hline 15 & $11^{\circ} 9^{\prime} 1.729^{\prime \prime} \mathrm{N}$ & $77^{\circ} 20^{\prime} 58.721^{\prime \prime} \mathrm{E}$ & Water Bodies & Yes \\
\hline 16 & $11^{\circ} 6 ' 21.937 " \mathrm{~N}$ & $77^{\circ} 14^{\prime} 0.512^{\prime \prime} \mathrm{E}$ & Water Bodies & Yes \\
\hline 17 & $11^{\circ} 6^{\prime} 16.592 " \mathrm{~N}$ & $77^{\circ} 13^{\prime} 45.709^{\prime \prime} \mathrm{E}$ & Waste Land & Yes \\
\hline 18 & $11^{\circ} 9^{\prime} 58.609 " \mathrm{~N}$ & $77^{\circ} 19^{\prime} 16.251^{\prime \prime} \mathrm{E}$ & Waste Land & Yes \\
\hline 19 & $11^{\circ} 4^{\prime} 0.014^{\prime \prime} \mathrm{N}$ & $77^{\circ} 17^{\prime} 4.103^{\prime \prime} \mathrm{E}$ & Waste Land & Yes \\
\hline 20 & $11^{\circ} 9^{\prime} 44.715^{\prime \prime} \mathrm{N}$ & $77^{\circ} 19^{\prime} 28.843^{\prime \prime E}$ & Scrub Forest & Yes \\
\hline 21 & $11^{\circ} 6{ }^{\prime} 23.009 " \mathrm{~N}$ & $77^{\circ} 16^{\prime} 56.357^{\prime \prime E}$ & Scrub Forest & Yes \\
\hline 22 & $11^{\circ} 6 ' 2.818^{\prime \prime} \mathrm{N}$ & $77^{\circ} 14^{\prime} 45.124^{\prime \prime} \mathrm{E}$ & Scrub Forest & Yes \\
\hline
\end{tabular}


Supervised classification methods for the land use change analysis depends on a combination of background professional knowledge and field experience. Thus per-pixel signatures are taken and stored in signature files by using this knowledge and the raw digital numbers $(\mathrm{DN})$ of each pixel in the scene are therefore converted to radiance values.

To understand land encroachment for different land categories during the last two decades, a change detection matrix (Table 4 and Figure $4 \& 5$ (a)-(d)) was prepared which reveals that:

- From the matrix Table 4 and Figure $3 \& 4$, there is a much conversion observed in the current fallow landwhich accounted for about 4439.43 hect area. Out of which, 2704.96 hect. land was converted from current fallow land to built-up area, 215.1 hect and 218.61 hect land area was converted to waste land and scrub forest respectively. In reverse, effective usage ofcurrent fallow land in 2001 has been attributed to about 1283.76 hect area from fallow land to crop and plantation put together. This marked difference in agricultural area may be due to increase in seasonal rainfall.

- $\quad 903.87$ hect. of agriculture - crop land was changed between the year 2001 to 2018 and it is noted that about 742.59 hect was occupied as current fallow land and 80.91 hect. as built-up land.

- An increased area under built-up usage between 2001-2018 is attributed by about 2704.95hect.from fallow land, 80.91 hect. from agricultural land and a very minimal settlement of about 4.23 hect.around water bodies with 13.05 hect. as waste land.

- Rapid urbanization due to population growth and industrialization may be the cause for this marked difference in agricultural area and an increased built -up area.

- From Figure 3, there is a massive variation in the waste land and scrub forest area, which accounts for about $1.29 \%$ (244.35 hect.) of waste land and $1.34 \%$ (253.24 hect.) of scrub forest area from the total land area (Table 3). Table 4 depicts that 215.1 hect. of waste land and 218.61 hect. scrub forest land was converted from current fallow land which is highestin comparison to all other land classes.

- Among the water bodies in 2001, about 26.94\% (8.91 hect.) has now been occupied as built-up area, $51.44 \%$ (17.01 hect.) as fallow land and $3.54 \%$ (1.17 hect.) for agricultural purpose in 2018 which may be attributed to the disposal of construction waste by landfills and encroachments.

- About 49.95 hect of fallow and crop land in 2001 has now been changed as plantation, a minor increase in plantation area of about 0.99 hect. wasfromwater bodies, waste land and scrub forest in 2018. This may be due to the coconut plantation along the banks of the water bodies.

\section{Conclusion}

The present study based on remote sensing and GIS was found to be an effective, easy tool in assessing the LULC changes through conventional mapping in the study area of Tirupur city in the last decade. The current quantitativestudyindicates that

- The maximum change in land use was noted in built-uparea by about $12.76 \%$. In that $55.57 \%$ was subsidized from current fallow land from 2001 to 2018 mainly due to the expansion of the city during the last decades. 
- During the study period (2001 - 2018), current fallow land has been decreased by $17.52 \%$ due to conversionin built-up land and agriculture.

- The next major category of land in the study area is agriculture land including crop land and plantation whichwas increased by $2.14 \%$ (403.59 hect) predominantly from current fallow land.

\section{References}

[1] Rajkumar, R. \& Elangovan, K. Impact of urbanisation on formation of urban heat island in Tirupur region using geospatial technique. Indian J. Geo-Marine Sci.49, 1593-1598 (2020).

[2] Pandian, M. \& Mangan, P. Land use and land cover change detection using remote sensing and GIS in parts of Coimbatore and Tiruppur districts, Tamil Nadu. Int. J. Remote Sens. Geosci.3 Issue 1, 15-20 (2014).

[3] Pawe, C. K. \& Saikia, A. Unplanned urban growth: land use/land cover change in the Guwahati Metropolitan Area, India. Geogr. Tidsskr. - Danish J. Geogr. 118, 88-100 (2018).

[4] Reddy, K. R., Devaraj, S., Biradar, S., Yarrakula, K. \& Srinivas Kumar, K. Spatial distribution of land use/ land cover analysis in Hanamkonda taluk, Telangana - A case study. Indian J. GeoMarine Sci.48, 1761-1768 (2019).

[5] Kumar Rai, P. \& Kumra, V. K. Role of Geoinformatics in Urban Planning. J. Sci. Res.55, 11-24 (2011).

[6] Jaafari, S. \& Nazarisamani, A. Comparison between Land Use/Land Cover Mapping Through Landsat and Google Earth Imagery. Am. J. Agric. Environ. Sci.13, 763-768 (2013).

[7] Srimathi, N., Sathishkumar, V. \&Elangovan K, Urban land use land cover change detection using remotely sensed data for Coimbatore City. Int. J. Earth Sci. Eng.7, 624-631 (2014).

[8] Freddy, A. J., Tennyson, S., Samraj, D. A. \& Roy, A. Detection Using Remote Sensing and Geographical Information System in Pathri Reserve Forest, Uttarakhand, India. in Contemporary Topics in Life Sciences 353-365 (2014).

[9] Kapilan, S. \& Elangovan, K. Potential landfill site selection for solid waste disposal using GIS and multi-criteria decision analysis (MCDA). J. Cent. South Univ.25, 570-585 (2018).

[10] Arumugam K and Elangovan, K, Hydrochemical characteristics and groundwater quality assessment in Tirupur Region, Coimbatore District , Tamil Nadu , India. Environ. Geol.58, 15091520 (2009).

[11] Y.Shantharam, Elangovan K, GROUNDWATER CHEMICAL STUDIES USING STATISTICAL ANALYSIS IN COIMBATORE CORPORATION, TAMIL NADU, INDIA Corresponding Author Mail ID : shantham1311@gmail.com Academic Discipline And Sub-Disciplines. J. Adv. Chem.12, 5752-5762 (2016).

[12] Arumugam, K., Rajesh Kumar, A. \& Elangovan, K. Assessment of groundwater quality using water quality index in Avinashi-Tirupur-Palladam Region, Tamil Nadu, India. Int. J. Appl. Eng. Res.9, 12177-12191 (2014).

[13] Allafta, H., Opp, C. \& Patra, S. Identification of groundwater potential zones using remote sensing and GIS techniques: A case study of the shatt Al-Arab Basin. Remote Sens.13, 1-28 (2021).

[14] Ramamoorthy, P. Land use and Land Cover Change Detection Using Remote Sensing and GIS , A Case Study of Nandhiyar Sub Basin , Tamil Nadu, India. Int. J. Sci. Technol. Eng.2, 213-216 (2016).

[15] Vishnuvardhan, K. \& Elangovan, K. Application of remote sensing and GIS for identifying suitable sites for solid waste disposal in Erode Corporation, Tamil Nadu, India. Indian J. Geo-Marine Sci.59, 1479-1485 (2020).

[16] Attri, P., Chaudhry, S. \& Sharma, S. Remote Sensing \& GIS based Approaches for LULC Change Detection - A Review. Int. J. Curr. Eng. Technol.5, 3126-3137 (2015).

[17] Veettil, B. K. \& Zanardi, R. P. A comparative study of various urban change detection techniques using high spatial resolution commercial satellite images: Quickbird and Worldview-2. Proc. 4th GEOBIA1, 76-84 (2012). 
[18] Afify, H. A. Evaluation of change detection techniques for monitoring land-cover changes: A case study in new Burg El-Arab area. Alexandria Eng. J.50, 187-195 (2011).

[19] Mishra, P. K., Rai, A. \& Rai, S. C. Land use and land cover change detection using geospatial techniques in the Sikkim Himalaya, India. Egypt. J. Remote Sens. Sp. Sci.23, 133-143 (2020). 